\title{
Erratum to: Perioperative management of an IgA-deficient recipient of a double-lung transplant
}

\author{
Asim Alam, MD • Christine M. Cserti-Gazdewich, MD
}

Published online: 4 July 2014

(C) Canadian Anesthesiologists' Society 2014

\section{Erratum to: Can J Anesth/J Can Anesth}

\section{(2014) 61:441-445 \\ DOI 10.1007/s12630-014-0133-x}

In the article entitled: "Perioperative management of an IgA-deficient recipient of a double-lung transplant" published in the May 2014 issue, Can J Anesth 2014; DOI: $10.1007 / \mathrm{s} 12630-014-0133-x$, the first line of the conclusion of the abstract should read: "Through a multidisciplinary approach...". The publisher apologizes most sincerely for this error.

The online version of the original article can be found under doi:10.1007/s12630-014-0133-x.

\footnotetext{
A. Alam, MD ( $\square)$

Department of Anesthesia, Sunnybrook Health Sciences Centre, 2075 Bayview Avenue, Toronto, ON M4N 3M5, Canada e-mail: asim.alam@sunnybrook.ca
A. Alam, MD - C. M. Cserti-Gazdewich, MD
Department of Laboratory Medicine \& Pathobiology, University of Toronto, Toronto, ON, Canada
C. M. Cserti-Gazdewich, MD
Division of Hematology, Department of Medicine, University of Toronto, Toronto, ON, Canada
C. M. Cserti-Gazdewich, MD
Transfusion Medicine, University Health Network, Toronto, ON, Canada 